\title{
Relationship Service Quality and Behavior Intentions: Favorable and Non-favorable Customers
}

\author{
Susetyo Darmanto \\ University of 17 Agustus 1945 Semarang, Semarang, Indonesia
}

\begin{abstract}
Customs clearance companies (EMKL) have important roles in international trades as mediator of transportation among exporters, importers, and shipping lines. The companies are facing high competitions in Tanjung Emas Port (Semarang) which affect the discreasing of companies numbers. Relationship between service quality and behavior intentions of customers is key factor to reach customer satisfaction. The main objective of this research is to analyze the relationship between service quality and behavior intention of favorable customers, the relationship between service quality and behavior intentions of non-favorable customers, and the relationship behavior intentions of favorable and non-favorable customers and service quality of custom clearance company. Sampels consisted of 100 exporters, testing empirical research using Multivariate Bivariate and one way analysis of variance (one way Anova). The result of this study showed that service quality had relationship with behavior intentions of favorable and non-favorable customers and behavior intentions of favorable and non-favorable had relationship on service quality. The findings indicate the importance of the service quality to create behavior intention in order to depend loyal customers.
\end{abstract}

Keywords: service quality, behavior intentions, favorable customers, non-favorable customers

\section{Introduction}

Transportation services sector got a big challenge of globalization, consolidation and, the need for speed, visibility, and flexibility of the supply chain. The existence of commercial custom clearance companies (EMKL) plays a very decisive effect on the smooth and import-export activities, because in international trade, most of the import-export goods transported by container through a containership. EMKL are one of the components of marine transportation services whose purpose is to facilitate and assist the implementation of import-export trade, thus simplifying the buyer (importer) and the seller (exporter) in carrying out the transaction. According to international Logistic and Forwarding Association of Central Java (GAFEKSI) in 2005, there were 110 companies engaged in the field of EMKL located at Tanjung Emas Port in Semarang. The companies are facing high competitions in Tanjung Emas Port Semarang which affect the discreasing of companies numbers. The existence of these firms' marine transportation services is expected to encourage and facilitate the process of trade both at home and abroad.

Susetyo Darmanto, Ph.D., Department of Management, Faculty of Economics and Business, University of 17 Agustus 1945 Semarang, Semarang, Indonesia.

Correspondence concerning this article should be addressed to Susetyo Darmanto, Pawiyatan Luhur Bendan Dhuwur, Semarang 50235, Indonesia. E-mail: susetyodarmanto@yahoo.co.id. 
Tabel 1

The Existance of EMKL Companies in Tanjung Mas Port, Semarang (2002 to 2005)

\begin{tabular}{llc}
\hline Year & Numbers of company & \% changes \\
\hline 2002 & 175 & \\
2003 & 162 & -7.49 \\
2004 & 144 & -11.11 \\
2005 & 110 & -23.61 \\
\hline
\end{tabular}

Some problems occurred in the dynamics faced by EMKL are:

(1) the entry of foreign sea freight forwarding company or EMKL with a more adequate infrastructure which has greatly reduced the volume of the domestic EMKL companies;

(2) the condition of infrastructure around the Port of Tanjung Emas which is offently effected by tide flood;

(3) highly rates of container handling charge in Indonesia.

Considering the complexity of the problem and the company's business competitive situation of EMKL, it should further strengthen the base strategy with concepts, such as customer-focused and market-oriented, to be able to access the market profitably and ensure sustainable growth (Ferdinand, 2000). Zeithaml, Barry, and Parasuraman (1996) suggested that previous researchers found an important relationship between the quality of services and financial performance, namely, in the form of behavioral intentions, which describes whether a consumer will survive or move to another company. If the quality of service delivered rated superior by consumers, behavioral intensions may be likely to be positive for the company, on the contrary, if judged inferior to the behavioral intensions tends to be negative. Another finding of the study (Zeithaml et al., 1996) stated that the experience gained an issue with the company which may affect consumer behavioral intentions. For consumers who do not have a problem, the service will have a perception of service quality significantly better than consumers who have recently experienced service problems, although it can be resolved satisfactorily. Thus, behavioral intensions of a consumer may be different in character between never troubled by the ever problematic. This study was designed to examine the relationship between the quality of service with behavioral intentions both favorable and unfavorable (non-favorable) indicated by the consumer based on his experience to get in trouble and settlement of the problems experienced at the time of the service received. Therefore, the focus of attention in this study is to reveal the relationship among consumer behavior exhibited consequences, as a result of the quality of service that has been received.

Based on the description above, the research tried to analyze service quality that has received consumer behavior associated with the intensions of favorable and non-favorable.

The purpose of the study is detailed as follows:

(1) to analyze the relationship between the service quality with behavioral intentions of favorable customers;

(2) to analyze the relationship between service quality with behavioral intentions of non-favorable customers;

(3) to analyze the differences of behavior intentions of favorable and non-favorable customer with the service quality.

\section{Literature Review}

\section{Service Quality}

Zeithaml (2000) formulated services as that service includes all activities economics whose output is not a physical product or construct which is generally consumed at the time it is produced and that service provides 
added value in the form (such as, convenience, amusement, timeless, comfort, or health) that are intangible essentially concerns of its first purchaser. Parasuraman, Zethhaml, and Barry (1988) developed an instrument measuring the quality of a service called SERVQUAL (service quality). SERVQUAL is a multi-item scale consisting of 22 questions, which can be used to measure customer perceptions of service quality, which includes five dimensions, namely: reliability, responsiveness, assurance, empathy, and tangibles. Bitner (1990), Boulding, Klra, Staelin, and Zeithaml (1993), Crosby, Evans, and Cowles (1990), Cronin and Taylor (1992) explained that the quality of service can strengthen consumers' willingness to stick with one company, therefore, if the customer moved, it will hurt the company. Consumer loyalty is caused by the influence of satisfaction or dissatisfaction with the product brand accumulated continuously in addition to the perception of the quality of the product (Boulding et al., 1993).

\section{Behavior Intentions}

Various studies about the quality of service and profit suggest that the relationship between service quality and profit is not straight forward or simple (Greising, 1994; Rust \& Zahorik, 1993). But between them, there is a relationship between or intermediate links (Zeithaml et al., 1996). Furthermore, they proposed a conceptual model that describes the consequences in the form of behavioral intentions as variable (intervening variable) between service quality and financial impact of retention and difection. The relationship starts from one's assessment of consumers towards a quality of service. If consumers' assessment of the quality of service is high (superior), then the behavior of the consumer intentions will be favorable (positive), which seeks to strengthen ties with the company, stating positive things about the company, remaining loyal to the company, recommending the company to others, increasing the volume of purchases, or are willing to pay a premium price. Conversely, when the behavior of consumer intentions is unfavorable (negative), then there is a possibility of a weak relationship with the company. Richins (1983) stated that consumer' perceive as inferior quality service is likely to show a certain behavior, such as severed ties with the company and complained. Behavior intentions can be seen as an indicator that signals whether consumers will remain loyal or switch (Zeithaml et al., 1996). Research result of Parasuraman, Zethhaml, and Barry (1993) suggested that there were two levels of consumer expectations for service quality: the level of service desired (desired service) and adequate service level (adequate service). Desired service is a level of expectation that consumers expect to be accepted, while adequate service is the level of service that will be accepted by consumers. The service level is the minimum service that can be given a company and still be expected to meet the basic needs of consumers. Both of these levels will be the boundary of an area called the tolerance zone (zone of tolerance). Tolerance zone is the area between adequate service and desired service, which is the area in which the variation of service is acceptable by the customer. If the customer service received is under adequate service, customers will be frustrated and disappointed. Whereas, if the service received exceeds the desired customer service, customers will be very satisfied.

\section{Interfirm Relationship Marketing}

At the high quality of the relationship, the contribution of different partners will strengthen the company and the degree of competition to encourage companies to integrated strategic (Garbarino \& Johnson, 1999). According to Morgan and Hunt (1994), the quality of relationships is taken into account in the relationship among partner companies. Continuity of a relationship among the company with its business partners is expected in the long term, in which it is most closely linked with a commitment that is built among them. 
Dwyer, Schurr, and Oh (1987) established the concept of the quality of the relationship as a construct that consists of several restrictions and interrelated dimensions. According to Schuur and Ozanne (1985) and Morgan and Hunt (1994) in the context of organizational, trust will result in a higher level of loyalty that is committed to its partners. Trust is measured by mutual trust, integrity, and consistency in partnering. The built trust will ensure a mutually beneficial long-term relationship on both sides (Garbarino \& Johnsons, 1999). The strategic goal is to maintain and enhance the relational ties that have been forged with business partners (Zeithaml et al., 1996).

Model development is based on the review of the literature. Then a theoretical model of the frame work is based on a literature review and the results of previous studies in Figure 1 below.

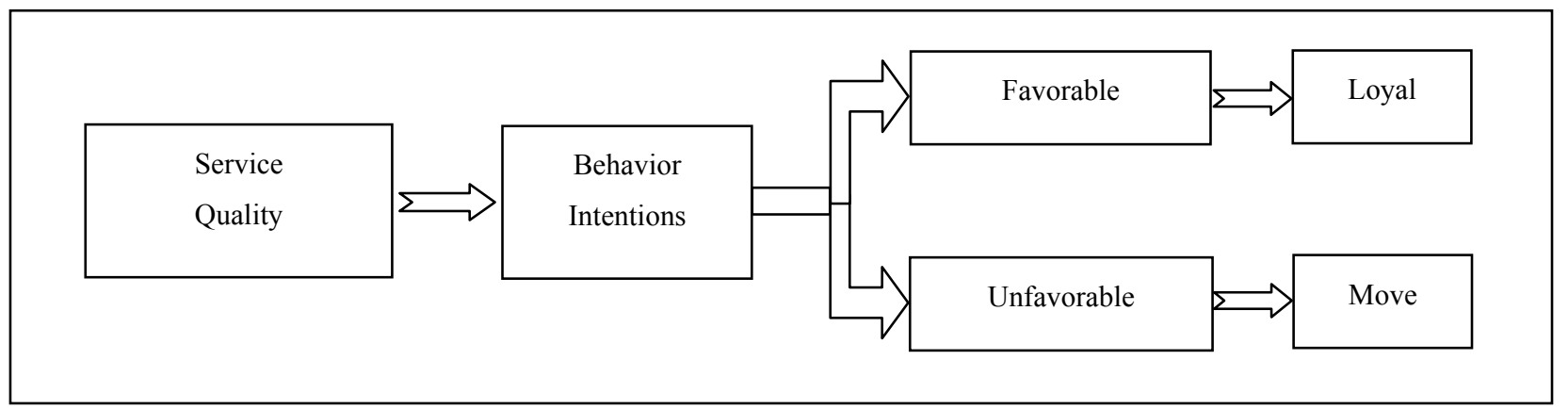

Figure 1. Theoritical framework.

Figure 1 above explains that the quality of service can affect the performance of the services and the perceived behavioral intention (the possibility of customer behavior) and behavioral intention is determined by experience ever facing the problem and the solution. When your experience of the issue is resolved, then the customer will have favorable behavior (pleasent), in the sense that loyal customer would like to express things positive, recommend the company, remain loyal to the company, do business more, and be willing to pay a premium price. Similarly, if the client has never had a problem, then he will behave the same. However, if the customer has the experience and the problem is not resolved, then the customer will have unfavorable behavior (unpleasent), in the sense that customers will move/disconnected as saying negative things, move to another company, compliant, and on the other hand, reduce the business.

\section{Hypothesis}

Based on the description in the literature and the results of previous studies, the hypotheses set out in this study are:

(1) Service quality has a positive and significant relationship with the customer intentions in favorable behavior;

(2) Service quality has a negative significant relationship with the customer intentions in unfavorable behavior;

(3) There are significant differences of behavior intentions of favorable and non-favorable customers associated with service quality

\section{Definition Operationalization and Indicators of Variables}

Service quality is measured through reliability, responsiveness, assurance, empathy, and tangibles. Behavior intentions of favorable customers are measured through telling the positive, giving recommendation 
to others, buying more, and willing to pay best price. Behavior intentions of non-favorable customers are measured through telling the negative, switching to other companies, reducing business, and complaining more.

\section{Research Method}

\section{Population and Sampling Techniques}

The population of this study is the importer-exporter total of 287 companies in minimum number of samples or the respondents in this study can be calculated with the formula of Rao (1996) and found as many as 100 samples. The sampling technique was conducted with a purposive sample technique (SnowBall), namely sampling by using certain criteria in accordance with the problems in this study by dividing customers into two groups:

(1) group of customers who have never had the experience problem, in which customers have expressed a behavior that is favorable intensions;

(2) group of customers who have had experience problem, which again is divided into two groups, namely:

- problems which ever experienced can be resolved properly: This group is expressed as a customer who has a behavior that is favorable intensions;

- problems which experienced can never be resolved properly: This group is expressed as a customer who has intensions that are unfavorable behavior.

\section{Method of Data Analysis}

Bivariate multivariate techniques are used to analyze the relationships positive or negative quality of service to customer whose behavior is favorable intensions. While analyzing differences in behavior intentions which are favorable and non-favorable associated with service quality used one-way analysis of variance (one-way ANOVA). This analysis is purposed to exam the differences of the average of two samples.

\section{Results and Discussion}

\section{First Hypothesis Testing}

Hypothesis testing is done by calculating the correlation coefficient, while the calculation by computing through the system SPSS is obtained with the results shown in Table 2 below.

Table 2

Result Correlation Coefficient Behavior SERQUAL With Intensions in Favorable Customer

\begin{tabular}{llcl}
\hline No. & Variable & Coefficient & Sig. \\
\hline 1 & Loyal & 0.631 & 0.000 \\
2 & Pay more & 0.541 & 0.000 \\
3 & Swich & -0.445 & 0.000 \\
4 & External response & -0.447 & 0.046 \\
\hline
\end{tabular}

Based on the correlation coefficient as shown in Table 2, the results showed that the first hypothesis that proposed that there is a relationship between the service quality (SERVQUAL) with behavioral intentions in the group of respondents who have never had a problem in service (favorable) was proved significant. The correlation coefficients are obtained for loyal variable coefficient of 0.631 and 0.541 for the variable pay more. The second variable has a positive sign, meaning that the higher quality of service EMKL will increase 
customer loyalty and customers are willing to pay the price set by the company. Instead, there is a relationship between service quality and switch of -0.445 and a relationship with the external response of -0.447 . Both have a negative sign. This means that when the company is getting the quality of service better, then the client will not take a decision to move or unpleasant information on the external (potential customers). The relationship between quality of service and the behavior has been shown to significantly intensions. This can be evidenced by the probability value obtained (Table 2). It appears that all probability are valueless than 0.05 . This means that the probability of rejecting Hofor four variables (loyal, pay more, switches, and external response) is approaching 100. Therefore, the hypothesis that there is a positive correlation among the quality of service to customers whose behavior intensions never experienced real problems is stated.

\section{The Second Hypothesis Testing}

Hypothesis testing is done by calculating the correlation coefficient, while the calculation by computing through the system SPSS is obtained with the results as shown in Table 3 below.

Table 3

Result Correlation Coefficient Behavior SERQUAL With Intentions in Unfavorable Customer

\begin{tabular}{llll}
\hline No. & Variable & Coefficient & Sig. \\
\hline 1 & Loyal & -0.527 & 0.044 \\
2 & Pay more & -0.557 & 0.031 \\
3 & Switch & 0.787 & 0.001 \\
4 & External response & 0.875 & 0.000 \\
\hline
\end{tabular}

Based on the correlation coefficients shown in Table 3, the results showed that the second hypothesis was proved significant. This can be evidenced by the probability value obtained (Table 3). It appears that all probability is valueless than 0.05 . This means that the probability of rejecting Hofor four variables (loyal, pay more, switches, and external response) respectively hypothesis put forward that there is a relationship between the quality of service (SERVQUAL) with behavioral intensions in the group of respondents who have never had a problem in service (unfavorable). The correlation coefficients are obtained for loyal variable coefficient of -0.527 and -0.557 for variable pay more. The second variable has a negative sign, meaning that customers who are having problems in service will lower the loyalty of customers and customers are not willing to pay the price set by the company. Instead, there is a relationship between service quality and switch of 0.787 and a relationship with the external response of 0.875 . Both have a positive sign. This means that when customers have had an unpleasant experience and the problem is not resolved in the service of the company, then the customer will take a decision to move or tell unpleasant information to external parties (potential customers). The relationship between service quality and customer behavior on unfavorable intensions has 0.044 for the loyal, 0.031 for pay more, and 0.001 to 0.000 for external switches and response. Thus, the hypothesis that there is a negative correlation among the quality of service to customers whose behavior intensions never experienced real problems is stated.

\section{The Third Hypothesis Testing}

Hypothesis testing is done by one-way analysis of variance (one way ANOVA), while the results of calculations by computing through the system SPSS are obtained shown in Table 4.

From the above table, it can be seen that there are significant differences in customer behavior intentions who has favorable experience and who has unfavourable experience. This is evidenced by data showing that all 
tests produced accept Ha. It can be seen from the significance that all is smaller than 0.05 . This means that for all possibilities declared, null hypothesis is rejected, because the tolerance limits acceptance of the null hypothesis of a maximum of $5 \%$. Based on the results of testing the above hypothesis, it can be explained that this analysis has proved the truth of the theory which explains a significant service quality and customer satisfaction (Cronin \& Taylor, 1992), and supports research by Zeithaml et al. (1996), whether a consumer will survive or move to the other company. If the quality of service delivered rated superior by consumers, behavioral intensions may be likely to be positive for the company, on the contrary, if judged inferior to the behavioral intensions tends to be negative. For consumers who do not have a problem, the service will have a perception of service quality significantly better than consumers who have service problems experience, although it can be resolved satisfactorily. The company stated that the key to achieving the organization's goals is to become more selective than the competitors in integrating marketing activities in order to determine and satisfy the needs and wants of the target market. Satisfying customers is an important target, because in addition to getting new customers, it will also create customers loyal customers. Retaining customers is more important than attracting customers, because the cost of maintaining is smaller than that of generating when losing customers.

Table 4

Result of ANOVA Test

\begin{tabular}{lllllrl}
\hline No. & Variable & $\begin{array}{l}\text { Favorable } \\
(\text { Group 1) }\end{array}$ & $\begin{array}{l}\text { Resolved } \\
\text { unfavorable } \\
\text { (Group 2) }\end{array}$ & $\begin{array}{l}\text { Unresolved unfavorable } \\
\text { (Group 3) }\end{array}$ & $F$-test & $F$-prob \\
\hline 1 & Loyal & 3.94 & 3.60 & 2.80 & 10.852 & 0.000 \\
2 & Pay more & 3.92 & 3.49 & 2.80 & 9.107 & 0.000 \\
3 & Switch & 2.68 & 2.74 & 3.47 & 5.542 & 0.005 \\
4 & External response & 2.66 & 2.83 & 3.40 & 3.199 & 0.045 \\
\hline
\end{tabular}

\section{Conclusions}

Service quality is shown to have a relationship with the customer tendencies to behave in certain ways, which has a positive relationship with behavioral intensions favorable and is shown by an indicator of consumer loyalty and the willingness of customers to pay the premium price (pay more). The results of this study support several studies that have been conducted by marketing experts like Bitner (1990), Crosby et al. (1990), Cronin and Taylor (1992), who explained that the quality of service can strengthen consumers' willingness to stick with one company, therefore, if the customer moved, it will hurt the company. Consumers will be satisfied, if the products have been purchased in accordance with expectations. Instead, consumers will feel dissatisfied, if the products have been purchased not in accordance with expectations. Satisfaction describes the response after the purchase of a consumer of the product which is believed to be right, or there is a match among what is expected by the consumer with product performance received (Bitner, 1990).

Service quality is shown to have a relationship with the customer to behave in a certain tendency to group customers with behavioral intentions which are not favorable behavior, seen from the tendency of customers to switch and make complaints on the external (external response). This is consistent with the research by Crosby and Stephens (1987), who found the displacement (switching) due to dissatisfaction overall, meaning that the purpose of a business is to create satisfied customers, which in turn can provide the creation of customer loyalty. Conversely, the perceived customer dissatisfaction will cause customers switching. This study also supports the research by Beatty, Kahle, and Homer (1991), stating that the consumer's emotional dissatisfaction of 
experience with the product causing consumers is interested in finding other brands outside the usual brand. This search can be done by other brands consumers obtaining information through the media, where the ultimate goal is to move the behavior of the brand (brand switching).

Differences in behavioral intentions based on experience got problems and potential solutions in each group were different significantly. Group of customers who never got in trouble has a high value on loyalty and pay more dimension, while the lowest value is contained in switch and external dimensions response. Groups of customers have experienced problems and the problem can be resolved satisfactorily under levels of behavioral intentions (loyalty, pay more), rate of which is higher than the group of customers in which the problem cannot be resolved satisfactorily. This study supports research by Richins (1983), stating that consumer' perceive as inferior quality service is likely to show a certain behavior, e.g. severed ties with the company and complain. So behavioral intention is seen as an indicator that signals whether consumers will remain loyal or not (Zeithaml et al., 1996).

\section{References}

Beatty, S. E., Kahle, L. R., \& Homer, P. (1991). Personal values and gift-giving behaviors: A study across cultures. Journal of Business Research, 22(2), 149-157.

Bitner, M. J. (1990). Evaluating service encounters: The effects of physical surroundings and employee responses. Journal of Marketing, 54, 69-82

Boulding, W., Klra, A., Staelin, R., \& Zeithaml, V. A. (1993). A dynamic process model of service quality: From expectations to behavior intentions. Journal of Marketing Research, 30, 7-27.

Cronin, J. J., \& Taylor, S. A. (1992). Measuring service quality: A reexamination and extension. Journal of Marketing, 56, 55-68.

Crosby, L. A., \& Stephens, N. (1987). Effects of relationship marketing on satisfaction, retention, and price in the life insurance industry. Journal of Marketing Research, 24, 404-411.

Crosby, L. A., Evans, K. R., \& Cowles, D. (1990). Relationship quality in services selling: An interpersonal influence perspective. Journal of Marketing, 54, 68-81.

Dwyer, F. R., Schurr, P. H., \& Oh, S. (1987). Developing buyer-seller relationship. Journal of Marketing, 51, 11-27.

Ferdinand, A. T. (2000). Manajemen Pemasaran: Sebuah Pendekatan Stratejik. Research Paper Series, 1, 1-55.

Garbarino, E., \& Johnson, M. S. (1999). The different roles of satisfaction, trust, and commitment in customer relationship. Journal of Marketing, 63(2), 70-87.

Greising, D. (1994). Quality—how to make it pay. Business Week, pp. 54-59.

Morgan, R. M., \& Hunt, S. D. (1994). The commitment-trust theory of relationship marketing. Journal of Marketing, 58, 20-38.

Parasuraman, A., Zethhaml, V. A., \& Barry, L. L. (1988). SERVQUAL: A multiple item sale for measuring customer perception of service quality. Journal of Retailing, 64, 12-40.

Parasuraman, A., Zethhaml, V. A., \& Barry, L. L. (1993). More on improving service quality measurement. Journal of Retailing, 69(1), 140-147.

Rao, P. (1996). Measuring consumer perceptions through factor analysis. The Asian Manager, 11, 28-32.

Richins, M. P. (1983). Negative word-of-mouth by dissatisfied customers: A pilot study. Journal of Marketing, 47, 68-78.

Rust, R. T., \& Zahorik, A. J. (1993). Customer satisfaction, customer retention, and market share. Journal of Retailing, 69, 193-215.

Schuur, P. H., \& Ozanne, J. L. (1985). Influence on exchange process: Buyers' preconceptions of a seller's trustworthiness and bargaining toughness. Journal of Consumer Research, 11, 939-953.

Zeithaml, V. A. (2000). Service quality, and the economic worth of customers: What we know and what we need to learn. Journal of the Academy of Marketing Science, 28(1), 67-85.

Zeithaml, V. A., Barry, L. L., \& Parasuraman, A. (1996). Behavioral concequences of service quality. Journal of Marketing, 60, $31-46$. 